\title{
Os ditados populares sobre o clima rememorados pela população rural das localidades de Pedregulho e Aparecida, no município de Restinga Sêca, RS
}

\author{
Common phrases about climate recalled by the rural population of \\ Pedregulho and Aparecida, in the municipality of Restinga Sêca, RS
}

\author{
Lucian Armindo da Silva Brinco', Mauro Kumpf Werlang"
}

\section{RESUMO}

A sabedoria popular, expressa através de ditos, ditados, provérbios, enfim, sobre as condições atmosféricas, é de extrema importância para os estudos de percepção climática. As pessoas, em decorrência do espaço geográfico pelo qual estão inseridas, com suas vivências/experiências e culturas, desenvolvem expressões populares distintas. Nesse sentido, o presente trabalho tratou de analisar os ditados populares sobre o clima rememorados pela população rural das localidades de Pedregulho e Aparecida, no município de Restinga Sêca, RS. Para atingir esse objetivo principal utilizou-se do triângulo metodológico apresentado por White (1977) e adaptou-se a metodologia proposta por Sartori (2005). Sendo assim, após os ditados relativos ao clima serem divididos em grupos, obteve-se o total de cento e trinta (130) sobre o comportamento da fauna e os processos atmosféricos; sessenta e um (61) em face das condições atmosféricas de céu, que envolveram o pôr do sol, halo, nuvens e vento e, para finalizar, mais dezenove (19) acerca das fases da lua e as condições meteorológicas. Todos os ditos mais relembrados pelos moradores da área de estudo, ainda, foram explicados, cientificamente, através da revisão bibliográfica.

Palavras-chave: Ditados populares; Localidades rurais; Percepção climática

\section{ABSTRACT}

The popular knowledge, expressed through sayings, proverbs, in short, about atmospheric conditions, is extremely relevant to the climatic perception studies. The people, due to the geographic space where they live, as by theirs life experience and cultures develop popular sayings that differ among each other. In this matter, this job analysed the common phrases about climate told by the rural population of Pedregulho and Aparecida, in the municipality of Restinga Sêca, RS. To achieve this main objective, the methodological presented by Whyte (1977) was used and the methodology proposed by Sartori (2005) was adapted. Thus, after the dictations regarding the climate were divided into groups, a total, it were obtained 130 popular sayings about fauna, 61 about the sky atmospheric conditions, involving the sunset, halo, clouds and wind; and 19 proverbs about the moon and the meteorology conditions. Furthermore, all of the sayings most remembered by the residents of the study area they were further explained scientifically through the bibliographic review.

Possui graduação em Geografia (Licenciatura Plena) pela Universidade Federal de Santa Maria (UFSM) - Santa Maria, RS, Brasil. E-mail. ORCID:

"Professor associado do Departamento de Geociências do Centro de Ciências Naturais e Exatas (CCNE) da Universidade Federal de Santa Maria (UFSM) - Santa Maria, RS, BrasilE-mail. ORCID 


\section{INTRODUÇÃO}

As atividades diárias do ser humano, desde as mais simples até as mais complexas, sofrem, de alguma forma, com a influência do clima. A saúde, as formas de vestuário, a estrutura da casa que habita, as plantas que cultiva, as decisões que toma para curto, médio e até mesmo longo prazo, enfim, recebem a interferência da sucessão dos estados de tempo de um dado lugar. Desse modo, cabe ao indivíduo ajustar-se ao meio atmosférico, que se apresenta na interface entre a sociedade e a natureza (SARTORI, 2014, 2016).

Nesse sentido, a agricultura é uma das práticas humanas que mais recebe a influência do clima, pois sofre com as intempéries climáticas, como os ventos, as geadas, as estiagens e os granizos. Já numa visão mais ampla, as condições atmosféricas interferem na escolha do período que melhor a planta se adapta, no preparo do solo, na semeadura, no manejo dos cultivos, no armazenamento, no transporte e na comercialização dos produtos (AYOADE, 1998).

Vale lembrar que mesmo com os vários avanços tecnológicos e científicos obtidos ao longo da história, tais como os satélites e as estações meteorológicas, que permitiram à sociedade possuir um certo domínio sobre as variáveis do tempo, o clima, no entanto, permanece como o componente mais importante do ambiente (AYOAD, 1998). Além disso, os prognósticos meteorológicos tratam de desvendar o futuro, que caracterizam-se por serem um dos campos repletos de incertezas, dada a complexidade e infinidade de processos atmosféricos para serem previstos (CUNHA, 1997).

$\mathrm{Na}$ interação entre sociedade e espaço geográfico, entretanto, deve-se salientar que as pessoas do meio rural, ao contrário das do urbano, desenvolvem uma percepção climática muito mais aguçada. Sartori (2014, p. 25) enfatiza que as populações da cidade passam a maior parte do tempo, especialmente nos dias de hoje, em interiores, nos condomínios fechados, que, por sua vez, acabam perdendo, "[...] mesmo que temporariamente, a habilidade intrínseca de se adaptarem, com maior rapidez, às mudanças ambientais".

Os sujeitos do meio rural precisam observar, corriqueiramente, as condições meteorológicas para desenvolverem suas tarefas, apresentam um contato mais direto e 
prolongado com a natureza do que o habitante do espaço urbano e, ainda, convivem com os animais domésticos, mas principalmente com os selvagens. Muitos moradores rurais, também, pela falta de acesso, não estão imersos nas mídias sociais como os habitantes das cidades. Portanto, todos esses aspectos que demostram a interação dos indivíduos do meio rural com o meio físico interferem, em dado grau, em suas percepções climáticas/ambientais.

Em decorrência do lugar/espaço geográfico pelo qual estão inseridas, bem como pelas suas vivências/experiências e culturas, pode-se dizer que as pessoas desenvolvem expressões populares distintas. Os ditados, ou também chamados de ditos, provérbios, adágios, são exemplos dessa forma de comunicação popular entre as pessoas e que elucidam/transparecem as formas pelas quais elas se manifestam na vida social e como se adaptam ao meio ambiente (MARIANTE, 1985, MONTENEGRO, 2008, SARTORI, 2005).

Os ditados populares sobre o clima, sendo frases curtas do senso comum, transmitidos de geração em geração, conforme Sartori (2003, 2005), expressam a mais autêntica forma de percepção ambiental e climática desenvolvida por uma pessoa em contato direto com o espaço. Um exemplo de dito muito utilizado no Estado do Rio Grande do Sul (RS) diz que "Cerração que baixa, sol que racha." Assim, é dentro da abordagem perceptiva que os ditados do tempo meteorológico passam a ser destacados. As expressões populares acerca do clima, como enfatiza Sartori (2003, p. 43), também não precisam ser "[...] apresentadas como fórmulas infalíveis e indiscutíveis para a previsão do tempo no meio rural, mas como a mais pura forma de expressar a interação homem-natureza."

Sobre os ditos populares dos fenômenos atmosféricos, toca salientar que muitos deles, apesar de serem utilizados no mundo inteiro, necessitam de um aprofundamento científico maior para explicá-los. Para muitos meteorologistas atuais, com um aparato tecnológico formidável, esses provérbios sobre o tempo e o clima também acabam sendo insignificantes. No entanto, são frequentemente recordados, essencialmente pelas pessoas do espaço rural e que "[...] resultam da sensibilidade e do tempo de permanência" do ser humano em um dado lugar, isto é, da "percepção do espaço vivido" (SARTORI, 2005, p.2).

Sendo assim, o presente trabalho tratou de analisar os ditados populares sobre o clima rememorados pela população rural das localidades de Pedregulho e Aparecida, no 
4 | Os ditados populares sobre o clima rememorados pela população rural das localidades de pedregulho e aparecida, no município de restinga sêca, RS

município de Restinga Sêca, RS (Figura 1). A importância do desenvolvimento deste estudo se deu na colaboração para as pesquisas de percepção ambiental e, principalmente, climática, pois esta última é pouco explorada pela comunidade científica.

Figura 1 - Localização da área de estudo em relação ao Estado do Rio Grande do Sul e ao município de Restinga Sêca.

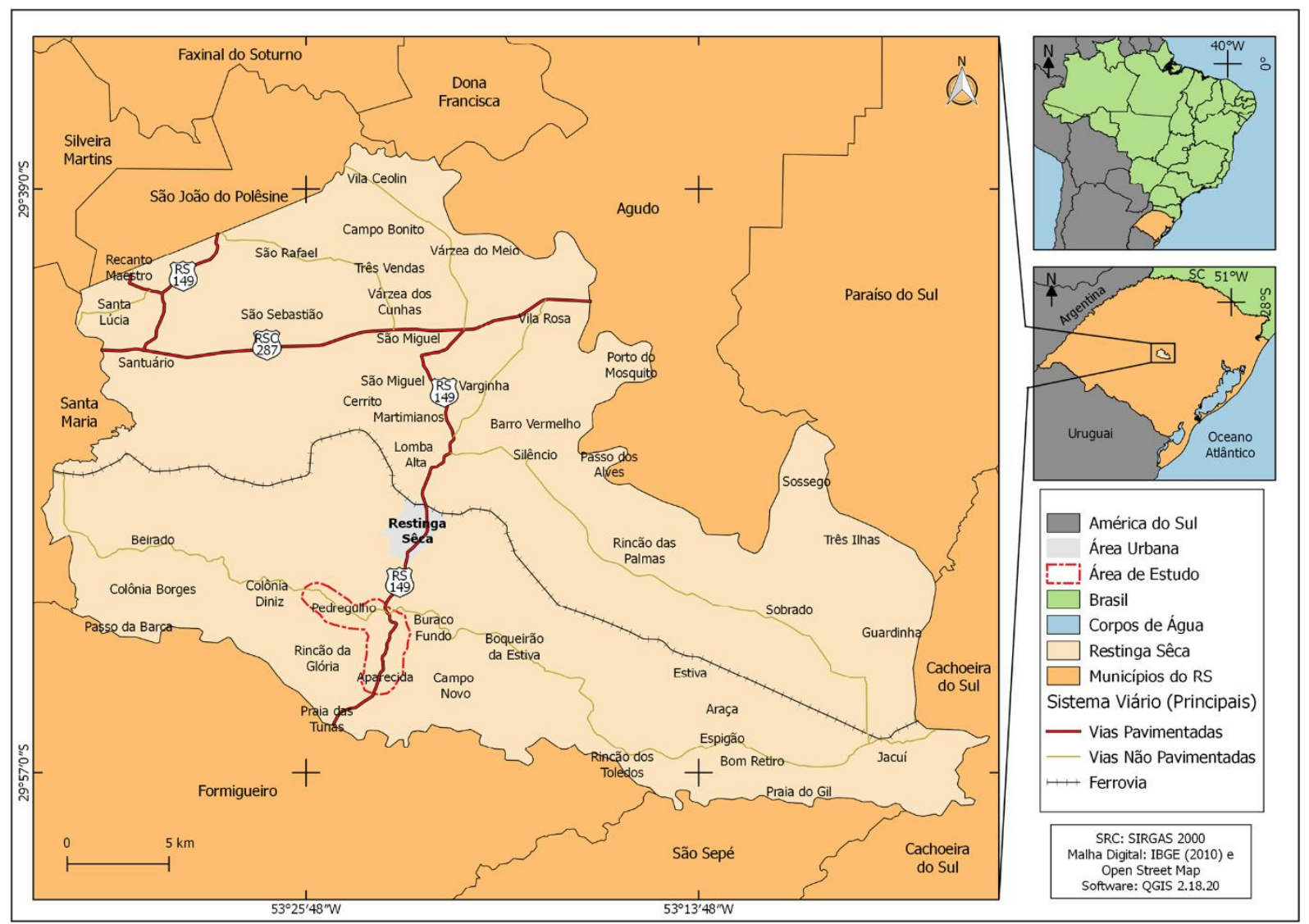

Fonte: Adaptação do IBGE (2010) elaborada pelos autores (2019).

A escolha pelas localidades de Pedregulho e Aparecida justifica-se pelo conhecimento das diversas atividades culturais, sociais e econômicas desenvolvidas pela comunidade local (cultivo de pomares; presença de culturas temporárias - arroz, soja e milho; criação de bovinos, suínos, equinos, por exemplo). Ademais, para a obtenção de uma amostragem mais representativa da população, optou-se por duas localidades ao invés de apenas uma, sendo que também predomina na área de estudo uma estrutura fundiária com pequenas e médias propriedades. 
Para isso, sempre em busca de comunicar suas partes de maneira integrada, organizouse o referencial teórico do presente trabalho em eixos: o primeiro tratou de discutir sobre a meteorologia popular; o segundo ponto resgatou a percepção climática; o terceiro enfoque se deu na caracterização climática do Estado do RS.

Como procedimentos metodológicos, utilizou-se, durante o trabalho de campo feito nas localidades rurais, para a aplicação das entrevistas, do Triângulo Metodológico de Whyte (1977), com os domínios de contração da pesquisa que se baseiam em "perguntar", "observar", "ouvir e registrar". No que se refere à forma de apresentação e análise dos resultados, adaptou-se a metodologia proposta por Sartori (2005).

Assim sendo, foram propostos três momentos de exposição e discussão dos resultados. O primeiro intitulou-se de "Ditados populares sobre o clima em relação ao comportamento dos animais", no qual foram apresentadas as expressões populares face às reações distintas da fauna aos processos atmosféricos. O segundo denominou-se de "Ditos populares sobre as observações das condições atmosféricas e céu", que envolveram as manifestações relativas às nuvens, pôr do sol, halos, ventos. O terceiro nomeou-se de "Ditados populares sobre o clima e as fases da lua", que permitiu a exibição das expressões populares que dizem respeito à interferência lunar sobre os fenômenos atmosféricos. Todos os ditados relembrados, ainda, ao longo da análise dos mesmos, foram explicados, cientificamente, através da revisão bibliográfica.

\section{REFERENCIAL TEÓRICO}

\subsection{Meteorologia popular}

Desde os tempos mais remotos, o ser humano sempre se interessou sobre o mundo astral e os inúmeros fenômenos meteorológicos. Astros como o sol, as estrelas e os cometas, bem como os fenômenos naturais (luminosos, ígneos, aquosos e elétricos), como, por exemplo, os raios, as tempestades e os terremotos, sempre se constituíram como objeto de pesquisa das pessoas. Acerca disso, criaram-se várias teorias, científicas e leigas, para explicarem tais acontecimentos (CUNHA, 1997; MARIANTE, 1985). 
A única forma de previsão das condições meteorológicas futuras, antigamente, davase em função da observação dos fenômenos naturais. Padata (2015, p. 204) salienta, no entanto, que "Até hoje, os efeitos desta pesquisa permanecem na língua, sendo memorizados na forma de provérbios. As informações transmitidas nos adágios, sejam cientificamente confirmadas ou baseadas nas crenças populares, são fruto da experiência do povo."

Para o presente trabalho, as manifestações populares transmitidas acerca dos ditados, ditos, adágios, provérbios, enfim, possuem o mesmo significado no sentido da palavra. Porém, sobre os "provérbios", Montenegro (2008, p. 29) coloca que o mesmo é fruto da observação dos humanos através do tempo, sendo que "[...] é a cristalização da experiência humana." Além do mais, na análise de cada dito popular é possível ter uma noção de como determinada cultura reage na vida social, isto é, como se expressa e, consequentemente, como se adapta ao ambiente no qual está inserida.

Vale ressaltar que os agricultores e/ou pecuaristas, para designar possíveis oscilações de tempo, não frequentaram nenhuma escola técnica que ministrasse os cursos de climatologia ou de meteorologia. Todo seu conhecimento é decorrente das constantes observações da natureza, de suas próprias experiências e que lhes foram transmitidas pelos seus antepassados. O tempo de permanência dessas pessoas também influência enormemente em suas percepções climáticas/ambientais (CUNHA, 1997; MONTENEGRO, 2008; SARTORI, 2003, 2005, TUAN, 1980, 1983).

Sartori (2005) salienta que toda a gama de informações e constatações sobre as condições atmosféricas permitiu que se criassem "regras" de previsão do tempo. Essas leis, expressas por meio de ditados, são, comprovadamente, tão antigas como a história da humanidade, sendo passadas/transmitidas de geração em geração.

Para muitas pessoas, os ditos populares não passam de crendices/superstições. Alguns meteorologistas, como destaca Montenegro (2008), acreditam que são superiores ao profeta de chuva - sertanejo de extrema importância para a história do Estado do Ceará e que utiliza de inúmeros ditados para fazer suas previsões climáticas - devido aos seus conhecimentos científicos e aparelhos meteorológicos. Por outro lado, existem, também, 
certos profetas de chuva que zombam do meteorologista pelas suas errôneas previsões. Há, ainda, aqueles que digam que as condições meteorológicas só pertencem a Deus.

Muitos dos provérbios que são tidos como superstições, como reafirma Sartori (2003, 2005), expressam uma das mais puras formas de percepção climática dessas pessoas. Embora não façam uso de aparelhos meteorológicos, seus ditos possuem explicações à luz do conhecimento científico.

O êxito e a difusão das deduções populares do tempo futuro, como salienta Clausse (1973), dependiam do prestígio de quem as elaboravam-nas. A relevância da afirmação da pessoa mais velha, considerando o fato de ser respeitada e ouvida, dava-lhe uma autoridade/notoriedade indiscutível. Assim, Clausse (1973, p. 58) coloca: "Transmitidos de geração em geração, e mais ou menos deformados nas transmissões sucessivas, não é de admirar que os adágios ou ditados relativos ao tempo tenham atravessado séculos."

O desenvolvimento científico e aperfeiçoamento dos instrumentos de observação da dinâmica atmosférica, de acordo com Bastos e Fuentes (2015), fez, por outro lado, com que as pessoas possuíssem acesso em segundos as informações do tempo, com uma maior probabilidade de acertos. Por conseguinte, agora elas passam a não se importarem muito com o conhecimento empírico que antes eram transmitidos ao longo das gerações.

Em algumas comunidades rurais, porém, um ramo da climatologia, chamado de "Climatologia Popular", "Meteorologia Popular" ou "Etnoclimatologia" faz-se presente e, em muitos casos, constituísse como a única forma de previsão do tempo. Essa é uma das realidades dos pequenos agricultores do semiárido baiano, que utilizam dos "prenúncios de chuva", sendo, na maior parte, "[...] uma das formas, ou única forma em certos casos, de previsão do Tempo acessível a esses indivíduos" (BASTOS; FUENTES, 2015, p. 176).

A população rural, para o prognóstico do tempo futuro, recorre ao "livro da natureza" (MONTINEGRO, 2008). São vários os sinais que a flora, a fauna, os astros, as nuvens e os ventos indicam sobre as mudanças atmosféricas. Acerca disso, criaram-se inúmeros ditados populares sobre esse comportamento anormal dos mesmos. Eles não são como termômetros, barômetros, anemômetros, mas, para os agricultores e/ou pecuaristas, suprem boa parte de suas necessidades, no que diz respeito às previsões meteorológicas (CUNHA, 1997; MONTINEGRO, 2008; SARTORI, 2003, 2005). 
Em suas pesquisas junto ao povo, no que trata-se de meteorologia popular, Mariante (1985) também salienta que os seus entrevistados geralmente resgataram algo referente a reação dos animais diante as alterações de tempo. O autor concluiu que esses seres vivos, de fato, domésticos ou selvagens, sempre reagem, de alguma forma, as mudanças atmosféricas.

Assim, para um bom espectador não passa despercebido de que os animais, em maior ou menor grau, conforme também a espécie, "indicam" as condições de tempo futuro, uma vez que eles apresentam comportamentos diferentes acerca de tais acontecimentos. A fauna apresenta-se como mais um elemento indicador, ou, talvez, como um primeiro alertador das preliminares oscilações de tempo. Além do mais, deve-se considerar que boa parte dos países espalhados pelo mundo possuem provérbios sobre as atitudes desses seres vivos frente as alterações da atmosfera (CUNHA, 1997; MARIANTE, 1985; SARTORI, 2005; VOSS, 1985).

Os animais estão, principalmente na atualidade, mais próximos da natureza do que o ser humano. Eles ficam mais tempo expostos às variações meteorológicas do que aquelas pessoas que passam a maior parte de seus dias em locais fechados, essencialmente no ambiente de trabalho, com climatizadores de ar, por exemplo. Condições como essas, sem dúvida, acarretam em reações/comportamentos bem distintos da fauna ao meio físico.

Os animais conservam modos sensoriais primitivos, boa parte desconhecidos pelos humanos. Outro aspecto de extrema importância, segundo Clausse (1973), é de que a fauna, sobretudo os seres silvestres, não ingerem uma variedade de medicamentos que podem afetarem, de algum modo, essas "percepções". Na interpretação dos estudos do autor, intendeu-se que as espécies apresentam uma possível "meteoro-sensibilidade" que Ihes permite perceber/reconhecer os deslocamentos/diferentes trajetórias para os seus abrigos em âmbito sazonal. Voss (1985), por outro lado, ressalta que os animais não "preveem" uma possível mudança de tempo. Eles se comportam de maneiras distintas devido as mudanças que por hora estão se processando.

Ademais, existem afirmações de que antes da chuva algumas espécies de ratos saem rapidamente de suas tocas, bem como as toupeiras entram e saem de suas tocas atordoadamente perante a aproximação de mau tempo. Tais comportamentos parecem 
compreensíveis, uma vez que essas criaturas vivem ao relento e, essencialmente, cujos abrigos subterrâneos podem ser inundados. Mas é importante refletir de acordo com as palavras de Clausse (1973, p.59), quando afirma que para isso ser plausível "[...] seria preciso que os animais profetas estivessem cercados por uma massa de ar que possua características do tempo que vai fazer, isto é, seja dotada de propriedades anunciadoras." suscitando mais estudos que analisem essa influência.

\subsection{Percepção climática}

Os ditados populares sobre o clima estão inteiramente ligados às análises acerca da percepção climática. Sartori $(2014,2016)$ enfatiza que perceber o clima representa papel estratégico no ajustamento do sujeito em relação ao seu meio ambiente, pois o clima apresenta-se na interfase entre a sociedade e natureza.

Em um primeiro momento é fundamental compreender o que caracteriza a percepção em si. Tuan (1980) considera-a como sendo a resposta dos sentidos humanos aos estímulos externos e que se baseia em atividades propositais, visto que alguns fenômenos são registrados e outros retrocedem ou são broqueados. O ser humano percebe de acordo com o valor que atribui sobre tal ambiente, seja até mesmo pela sobrevivência biológica ou pelas satisfações imbricadas em sua cultura.

A percepção pode ser descrita, conforme Oliveira e Nunes (2007), como o conhecer através dos sentidos as diferentes situações e objetos que estão ao seu redor, organizandoas interiormente a partir do mundo exterior. As pessoas percebem simultaneamente por meio de todos os sentidos e é imensa a gama de informações que são proporcionadas. Além do mais, acerca de sua personalidade, experiências, anseios/desejos que os indivíduos percebem o mundo.

Desse modo, pode-se dizer que os processos que ocorrem no planeta são extremamente variáveis. No entanto, as maneiras como os indivíduos percebem o que está ao seu redor também são excessivamente distintas. Dois irmãos, por exemplo, podem ser filhos dos mesmos pais, morarem na mesma casa, compartilharem de traços comuns que, mesmo assim, não veem ou avaliam uma dada realidade da mesma forma. 
Vale ressaltar que dos cinco sentidos tradicionais o que o indivíduo mais utiliza para progredir no mundo é o da visão. A gama de informações potencialmente disponíveis por ele é imensa. Tuan (1980, p.7) coloca que o ser humano "[...] é predominantemente um animal visual." Um novo e significativo horizonte lhe abre através desse sentido, pois são infinitas as informações que, espacial e detalhadamente, chegam até ele através de seus olhos, se comparados aos modos sensoriais de audição, paladar, tato e olfato.

Todavia, deve-se frisar a importância de todos os sentidos, pois uma pessoas que somente vê um dado lugar é um observador/um expectador, alguém que não possui nenhum envolvimento com o local ou sena. Perceber o mundo apenas com o sentido da visão é, consequentemente, mais abstrato do que pela integração dos demais sentidos. Outro ponto é que o sentido mais estimulado depende da própria cultura (TUAN, 1980; 1983).

A percepção é essencialmente exploratória e seletiva, como ressaltam Oliveira e Nunes (2007). Isso se dá pelas diferenças de idade, de gênero, de classe social, do nível de escolaridade, da profissão, do lugar de moradia e da cultura. Portanto, mesmo que os indivíduos apresentem órgãos sensoriais similares, com percepções comuns, são diferentes as capacidades de apreensão e as atitudes. No geral, nota-se que, no primeiro momento, a percepção é individual, com influência das memórias, valores e experiências prévias e, na sequência, atuam "filtros" socioculturais.

Em seus estudos sobre topofilia (que corresponde ao sentimento de amor pelo lugar), Tuan (1980) ressalta sempre o papel da cultura quando fala em percepção. Ele enfatiza que nos lugares onde os papéis dos sexos são fortemente definidos, culturalmente, homens e mulheres percebem seus mundos e atribuem atitudes diferentes para com o mesmo. Pessoas dos espaços urbanos e do rurais, evidentemente, apresentam percepções bem distintas entre elas.

Machado (1988, p. 2 apud SARTORI, 2014, p. 25) afirma que "cada ser humano é único, sem precedente e não repetível e por isso cada pessoa percebe, sente e compreende diferentemente o mesmo meio ambiente." Desse modo, tanto a percepção ambiental, como a climática depende, impreterivelmente, do modo individual do sujeito em relação com o espaço que o circunda. 
Em um sentido amplo, pode-se dizer que a percepção climática é o resultado do processo interativo entre o ser humano e o meio ambiente. Esse processo se dá em função dos sentidos, que levam as mais diversas sensações e, por conseguinte, às percepções (SARTORI, 2003, 2005). A percepção é comum entre os sujeitos, todos compartilham de trações perceptivos parecidos. No entanto, cada ser humano é único, possuí a sua essência, suas experiências/seu espaço de vivência. No momento em que se considera as características perceptivas comuns e, ao mesmo tempo, a unicidade do ser humano, os sentimentos, as percepções e as compreensões sobre o clima, o meio físico, em geral, são muito complexas e diversificadas.

\subsection{0 clima do Rio Grande do Sul}

O território gaúcho, assim como toda a região sul do Brasil, de acordo com Sartori (2003, p. 28), está localizado em uma zona de transição, considerando sua caracterização climática. Existe a atuação tanto de "Sistemas Atmosféricos Extratropicais (massas e frentes polares)" como os "Intertropicais (massas tropicais e Correntes Perturbadas)". Porém, os primeiros que controlam, por cerca de $90 \%$ dos dias do ano, os tipos de tempo atuantes sobre o Estado.

Em síntese, como coloca Sartori (2003, p. 28), "[...] o avanço sistemático dos Sistemas Atmosféricos de origem polar em direção aos polares tropicalizados (Massa Polar Velha MPV) ou aos sistemas de origem tropical (Massa Tropical Atlântica ou Continental)", da origem ao surgimento do clima subtropical, onde ocorre o "confronto periódico entre forças opostas". Logo, isso fornece chuvas para todo o ano, sendo ocasionada pela sequência de passagens frontais, no qual não há períodos de seca no regime pluviométrico.

Além do mais, os sistemas extratropicais (de origem polar) que atuam na Região sul e com circulação secundária no RS são definidos por Sartori (2003, 2016) como: Massa Polar Atlântica (MPA), Massa Polar Velha (MPV) e Frente Polar Atlântica (FPA), sendo que está última também recebe o nome de frente fria. Em contra partida, sobre os sistemas intertropicais que agem nesse território, são representados pela Massa Tropical Atlântica 
12 | Os ditados populares sobre o clima rememorados pela população rural das localidades de pedregulho e aparecida, no município de restinga sêca, RS

(MTA), ou Continetalizada (MTAc), Continental Massa Tropical (MTC), Frente Quente de Nordeste e Instabilidades Tropicais (ITs).

\section{METODOLOGIA}

A pesquisa no meio rural ocorreu através de entrevistas com os moradores das localidades de Pedregulho e Aparecida. As duas comunidades possuem, cada uma, em torno de trinta (30) moradores. Assim, a amostragem foi de doze (12) pessoas em cada localidade, o que corresponde à $40 \%$ de entrevistas feitas em relação ao número total, isto é, sobre a soma de todos os sujeitos da área de estudo.

Dessa forma, para a aplicação das entrevistas, o instrumento desencadeador desse trabalho enquadrou-se no triângulo metodológico (Figura 2) proposto por White (1977). O esquema consiste, basicamente, em "perguntar", "observar" e "ouvir e registrar".

Figura 2 - Triângulo metodológico utilizado durante os trabalhos de campo.

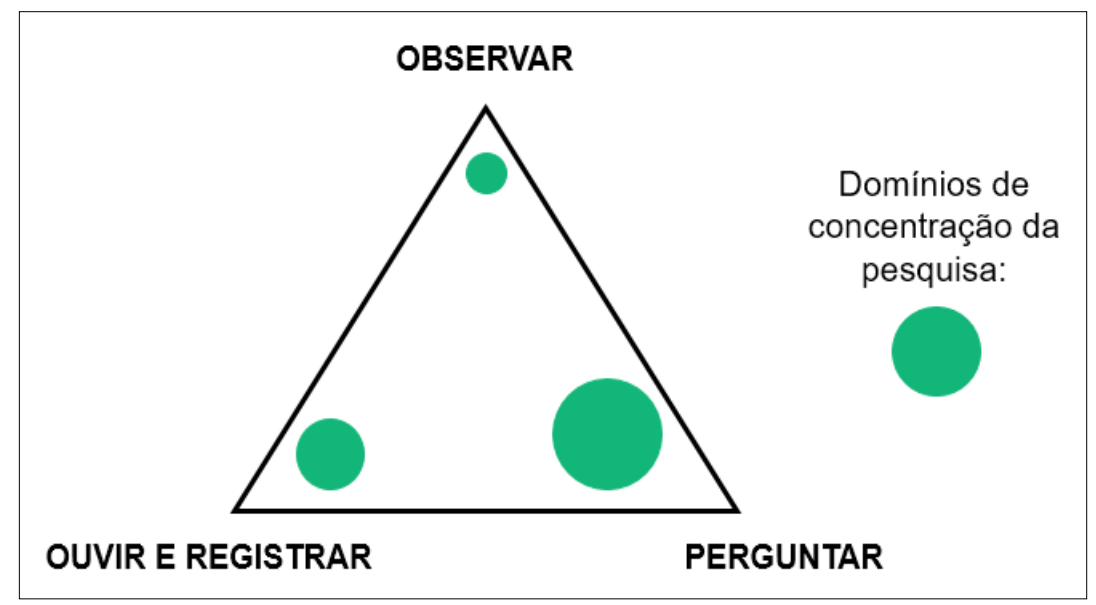

Fonte: Adaptação de White (1977. p.19).

Boa parte das pesquisas encontradas, durante a soldagem teórica, utilizaram e enfatizam a importância do Triângulo metodológico de White (1997) para os estudos acerca da percepção climática e ambiental. Esses trabalhos foram o de Rouso (2007), Sartori (2005), Wollmann e Sartori (2010) e Wollmann e Galvani (2013). 
A execução das entrevistas nas localidades de Pedregulho e Aparecida também se deram em dois momentos - através de dois trabalhos de campo. Efetuou-se o primeiro na localidade de Aparecida e o segundo em Pedregulho. Após o registro dos dados pessoais dos moradores foram feitas perguntas para o levantamento dos ditados populares sobre o clima nessas duas comunidades.

No que se trata das características sociais dos entrevistados, obteve-se que a média de idade foi de cinquenta e um (51) anos; treze (13) dos indivíduos eram do sexo feminino e onze (11) do masculino; uma (1) das moradoras era analfabeta, treze (13) possuíam ensino fundamental incompleto e três (3) completo, dois (2) com ensino médio incompleto e três (3) completo e, por fim, dois (2) com formação superior. Já sobre as profissões dos respondentes, averiguou-se que haviam onze (11) agricultores, dois (2) pedreiros, um (1) servente de pedreiro, um (1) motorista, um (1) pecuarista/agricultor, uma (1) operadora de caixa de supermercado, uma (1) enfermeira e um (1) advogado, sendo que dois (2) se consideraram estudantes e três (3) como donas de casa. Demais, o tempo médio de moradia dos moradores da área de estudo foi de trinta e um (31) anos.

Por fim, os ditos populares rememorados pela população da área de estudo, com base na metodologia proposta por Sartori (2005), foram divididos em três grupos distintos. O primeiro foi sobre o comportamento da fauna, o segundo acerca das condições de céu, halos, ventos e do pôr do Sol e, por último, em relação as fazes da lua. Para explicar, cientificamente, os ditados populares sobre o clima que foram rememorados pelos moradores das localidades de Pedregulho e Aparecida, fez-se a revisão bibliográfica acerca dessas temáticas. Cabe lembrar que, em geral, apenas Sartori $(2003,2005)$ que tratou, efetivamente, de analisar os ditados populares sobre o clima/tempo.

\section{RESULTADOS E DISCUSSÕES}

\subsection{Ditados populares sobre o clima em relação ao comportamento dos animais}


14 | Os ditados populares sobre o clima rememorados pela população rural das localidades de pedregulho e aparecida, no município de restinga sêca, RS

O grupo que mais apresentou ditados/expressões populares sobre o clima, após a realização do trabalho de campo nas localidades de Pedregulho e Aparecida, foi sobre o comportamento distinto da fauna em relação aos processos atmosféricos. O número total de ditos rememorados pelos vinte e quatro (24) entrevistados acerca da atitude distinta dos animais foram de cento e trinta (130). No entanto, vale lembrar que muitos se repetiram. No Quadro 1 foram expostos os provérbios com o número de vezes que foram citados, juntamente com a sua porcentagem em relação ao total de entrevistados. Após aglutinação, buscou-se explicações científicas para as expressões mais corriqueiras.

Quadro 1 - Ditados populares e/ou expressões relativas aos comportamento dos animais diante das mudanças de tempo nas duas localidades rurais

\begin{tabular}{|c|c|c|}
\hline $\begin{array}{l}\text { Ditados populares de acordo com reações dos } \\
\text { animais }\end{array}$ & $\begin{array}{c}N^{\circ} \text { de vezes } \\
\text { que os } \\
\text { ditados } \\
\text { foram } \\
\text { citados }\end{array}$ & $\begin{array}{c}\text { \% em relação } \\
\text { ao } \mathrm{n}^{\circ} \text { de } \\
\text { moradores } \\
\left(\mathrm{N}^{\circ}=24\right)\end{array}$ \\
\hline "Bugio roncando no mato é sinal de chuva" & 15 & 62,5 \\
\hline $\begin{array}{c}\text { "Bicho preto subindo a coxilha é sinal de muita } \\
\text { chuva" }\end{array}$ & 6 & 25 \\
\hline "Bicho preto descendo a coxilha é sinal de seca." & 5 & 21 \\
\hline "Bicho preto anuncia temporal." & 3 & 12,5 \\
\hline "Saracura cantando na sanga é chuva." & 3 & 12,5 \\
\hline "Saracura quando canta, daqui três dias chove" & 1 & 4,1 \\
\hline "Sapo roncando a cuia é sinal de chuva." & 5 & 21 \\
\hline "Sapo roncando é sinal de chuva." & 4 & 16,6 \\
\hline $\begin{array}{c}\text { "Sapo quando tá cantando de manhã é sinal de } \\
\text { chuva." }\end{array}$ & 2 & 8,3 \\
\hline "Seriema quando canta é sinal de chuva." & 8 & 33,3 \\
\hline "Seriema canta, daqui três dias chove" & 2 & 8,3 \\
\hline "Quando os passarinho tão voando baixo é chuva." & 1 & 4,1 \\
\hline "As galinhas se catando é sinal de chuva." & 2 & 8,3 \\
\hline "As galinha se esponjando na areia vem chuva." & 1 & 4,1 \\
\hline "As galinhas se catam pra parar de chover." & 1 & 4,1 \\
\hline "Galinhas cantado muito, vai chover" & 1 & 4,1 \\
\hline $\begin{array}{c}\text { "As galinhas no pátio se amontoando, fazendo } \\
\text { rodinha, sinal de chuva." }\end{array}$ & 1 & 4,1 \\
\hline "Minhoca saindo fora da terra é sinal de chuva." & 2 & 8,3 \\
\hline
\end{tabular}




\begin{tabular}{|c|c|c|}
\hline $\begin{array}{l}\text { "João-de-barro sempre faz a abertura da casa } \\
\text { contra o vento da tormenta" }\end{array}$ & 6 & 25 \\
\hline "Cigarra quando canta é sinal de chuva." & 1 & 4,1 \\
\hline $\begin{array}{l}\text { "O galo canta, as galinha se arrepiam, se ourição, } \\
\text { em } 24 \text { horas chove." }\end{array}$ & 1 & 4,1 \\
\hline $\begin{array}{c}\text { "Pato batendo asa, tomando banho, é sinal de } \\
\text { chuva." }\end{array}$ & 1 & 4,1 \\
\hline $\begin{array}{c}\text { "Quando o gado se embola antes da chuva, vem } \\
\text { temporal ou muita chuva." }\end{array}$ & 5 & 21 \\
\hline $\begin{array}{c}\text { "As vacas indo pra estrebaria quando se arma o } \\
\text { tempo é sinal de muita chuva." }\end{array}$ & 1 & 4,1 \\
\hline "Perdiz cantando de tardezinha é chuva." & 1 & 4,1 \\
\hline "Papagaio passando vem chegando o verão." & 1 & 4,1 \\
\hline "Quando canta o joão-de-barro é tempo bom." & 2 & 8,3 \\
\hline "Aracuã quando tá cantando é sinal de chuva." & 1 & 4,1 \\
\hline "Rã cantando vai chover." & 3 & 12,5 \\
\hline "Formiga corredeira aparecendo é sinal de chuva." & 4 & 16,6 \\
\hline "Formiga de asa aparecendo é sinal de chuva." & 2 & 8,3 \\
\hline "Gato de olho vermelho é sinal de chuva." & 1 & 4,1 \\
\hline "Burro 'gritando' vem chuva." & 2 & 8,3 \\
\hline "Macaco roncando é sinal de chuva." & 1 & 4,1 \\
\hline "Bem-te-vi cantando é sinal de chuva." & 1 & 4,1 \\
\hline "Pica pau muito agitado é sinal de chuva." & 1 & 4,1 \\
\hline "Quero-quero gritando no telhado é sinal de chuva." & 1 & 4,1 \\
\hline "As borboletinhas aparecem quando tá pra chover." & 1 & 4,1 \\
\hline "Corruíra cantando vem chegando a primavera." & 1 & 4,1 \\
\hline $\begin{array}{c}\text { "Caturritas gritando muito nas arvores é sinal de } \\
\text { chuva." }\end{array}$ & 1 & 4,1 \\
\hline "As lesmas aparecendo vem chuva." & 1 & 4,1 \\
\hline $\begin{array}{l}\text { "Quando as rolinha começam a canta de manhã vai } \\
\text { fazer muito calor durante o dia." }\end{array}$ & 1 & 4,1 \\
\hline "Sabiá cantando vem chegando o verão." & 2 & 8,3 \\
\hline "Pomba gritando vem calorão." & 1 & 4,1 \\
\hline "Caturrita muita conversadeira vem chuva." & 1 & 4,1 \\
\hline "Passarinho tomando banho vai chover." & 1 & 4,1 \\
\hline $\begin{array}{c}\text { "Quero-quero parado no ar, sacudindo as assas } \\
\text { vem chuva." }\end{array}$ & 1 & 4,1 \\
\hline "Aparecendo muitas pulgas é sinal de chuva." & 1 & 4,1 \\
\hline $\begin{array}{c}\text { "Andorinha chegando, vem chegando o verão } \\
\text { também." }\end{array}$ & 1 & 4,1 \\
\hline
\end{tabular}

Fonte: Acervo particular dos autores (2019). 
16 | Os ditados populares sobre o clima rememorados pela população rural das localidades de pedregulho e aparecida, no município de restinga sêca, RS

Na interpretação do Quadro 1, averiguou-se que o animal mais referido nas duas localidades rurais, através dos ditos populares, foi o Bugio (com 62,5\% de sujeitos que o citaram). Esses seres vivos são os representantes do gênero Alouatta, também conhecidos, popularmente, como "guaribas", "roncadores" ou "barbados" (Figura 3), sendo que, se comparados aos demais primatas, são os que possuem a maior distribuição geográfica da região neotropical. No casso do Brasil, seu habitat natural é no Estado do RS (GUZZO, 2009).

Figura 3 - Macacos Bugios que podem ser encontrados na área de estudo do presente trabalho.

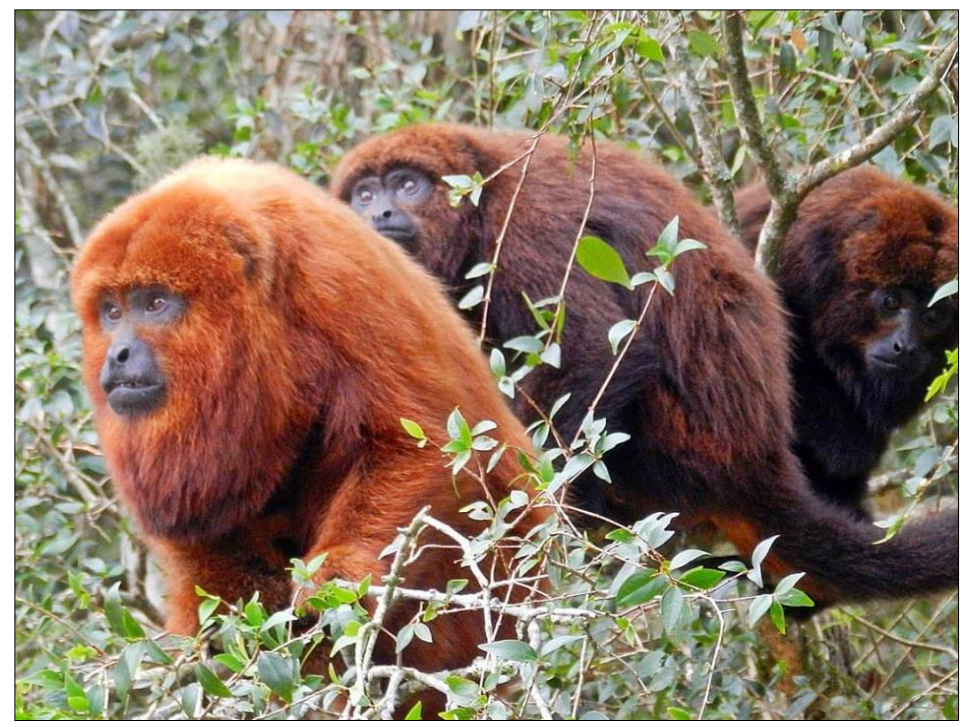

Figura 3 - Macacos Bugios que podem ser encontrados na área de estudo do presente trabalho.

Fonte: Elisângela Lopes (2020).

Conforme os sujeitos das localidades de Pedregulho e Aparecida, "Quando os bugios estão roncando no mato é sinal de chuva." O ditado é explicado, cientificamente, de acordo com Sartori $(2003,2005)$, pelo fato dos primatas serem bastante sensíveis, essencialmente, às mudanças bruscas de pressão atmosférica, o que permitem "anunciar", através de uma maior intensidade de seu ronco, a aproximação de chuvas, relacionadas as características pré-frontais que atingem o RS.

As lagartas pretas (Figura 4) apareceram em segundo lugar (com 58,5\% de pessoas que a referiram). Elas são larvas de vespas, do gênero Perreyia (SARTORI, 2003, 2005). Popularmente, são chamadas pela população rural de "bichos pretos" ou de "mata porcos", 
sendo que, de acordo com os entrevistados, como o último nome já pressupõem, são tóxicos aos suínos, matando-os em menos de dois dias.

Figura 4 - Lagartas pretas se deslocando pelo campo na localidade rural de Aparecida.

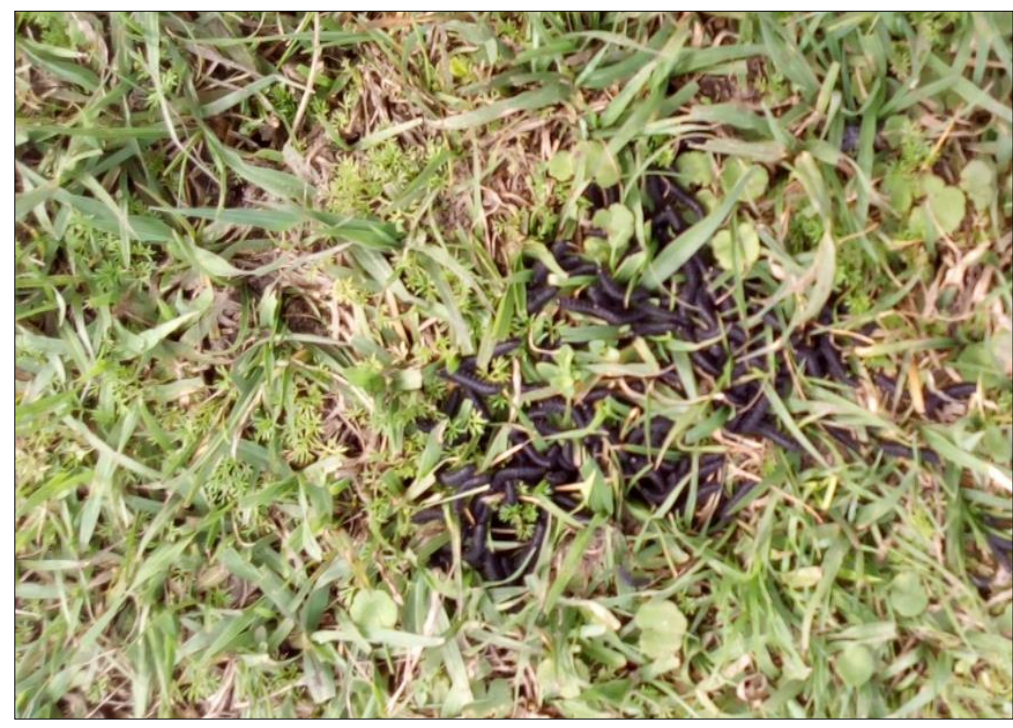

Fonte: Acervo particular dos autores (2019).

As larvas são pequenas, medem em torno de três (3) centímetros cada uma, sendo que se movimentam pelos campos amontoadas e que, segundo a população de Pedregulho e Aparecida, "Quando os bichos pretos estão subindo a coxilha é sinal de chuva e/ou temporal." Outro fato bastante interessante é que vários dos entrevistados citaram a música que se chama - "Bicho da chuva" - do cantor e compositor gaúcho, Ênio Medeiros, que, em sua canção, sobre as lagartas pretas, coloca

Os bicho-preto vem subindo na coxilha Anunciando vento frio e temporal Vem caminhando uns em cima dos outros Ladeira a cima fugindo do banhadal

Só quem entende a previsão dos home antigo E observa o jeito dos animais Espera agosto com a tulha cheia de bóia Batata doce, linguiça nos varais

Meu ponche velho que me abriga do rigor E eu vou contando pra esses jovens de caderno Que nunca viram uma lagoa virar vidro Nem bicho-preto anunciar o rigor do inverno [...] Ênio Medeiros. 
Dessa maneira, nos versos dessa música fica nítida a influência que o contato com os animais exerce sobre a percepção climática e ambiental, principalmente da população rural. O músico salienta, ainda, sobre o tempo de permanência em um dado lugar, das experiências/da vivência que lhes permitem prever o bom e mau tempo.

No que se refere às explicações do comportamento das larvas, foi encontrado apenas o trabalho de Sartori (2005, p.7). Segundo a autora as lagartas se deslocam em direção as superfícies mais altas com o objetivo de escapar dos alagamentos e das enchentes que ocorrem nas áreas mais baixas, pois possuem "sistemas sensoriais de seu organismo" capasses de perceber/sentir as alterações atmosféricas que estão se processando. No entanto, ela ressalta que esses mecanismos perceptivos são desconhecidos pelo ser humano.

Na terceira colocação, constatou-se que foram os anfíbios da ordem Anura os mais citados pelos moradores da área de estudo (com 58,4 \% dos ditados). Os sapos do gênero Bufo apresentaram o total de 45,9\% de pessoas que o rememoraram. Já as rãs do gênero Rana (SARTORI, 2003,2005) corresponderam à 12,5\% de algum ditado sobre ela. Portanto, para as pessoas das duas localidades, "Quando o sapo ronca a cuia é sinal de chuva."

O coaxar dos anfíbios é relacionado ao ronco da bomba do chimarrão. Nota-se, através desse ditado, a influência que os meios culturais exercem sobre a percepção climática dos seres humanos, uma vez que, transmitida de geração em geração, a partir dos ditos populares, é capaz de indicar mudanças de tempo, mesmo que em curto prazo. Esse comportamento distinto, explicado em face do conhecimento científico, diz respeito às sensibilidades diante das variações de pressão atmosférica e de umidade.

Sartori (2005, p.10) salienta que "[...] alguns estudos explicam essa sensibilidade à pressão atmosférica por um sistema de recepção sensorial próprio dos anfíbios, os 'neuromastos' cuja função é 'mecanoreceptora', sensíveis à corrente de água e à pressão." Dessa forma, de acordo com a autora, os sapos aumentam a intensidade do coaxar indicando que a chuva está próxima, devido ao seus sistemas receptores sentirem a diminuição da pressão do ar, que sempre antecede a chegada das frentes frias ou instabilidades tropicais no RS. 
Em seguida, dentro do grupo dos animais, a mais citada foi a Saracura (com 49,9 dos moradores que a indicaram). Ela é, cientificamente, considerada uma ave de ordem Gruiforme, da família Rallidae. Também é conhecida como "saracura-do-brejo" e "siricoia". Sua distribuição geográfica abrange o sul e sudeste do Brasil. Mede em torno de trinta e quatro (34) centímetros de comprimento. Essa ave também possui pernas longas e finas que, ao invés de voarem, correm pelos matos (SCHMIDT; GABRIEL, 2019).

Além do mais, a saracura é uma ave bastante desconfiada, visto que passa a maior parte do tempo escondida na vegetação. Apenas durante a tarde é mais fácil de encontrála, pois sai dos interiores das florestas para se alimentar de insetos e crustáceos (SCHMIDT; GABRIEL, 2019). Desse modo, conforme os entrevistados, "Quando a saracura canta é sinal de chuva". Sartori (2005) explica que por essa ave cantar, habitualmente, no entardecer, se o fizer em outro horário, principalmente de manhã, é porque sentiu alguma mudança de tempo. Isso se dá por elas serem sensíveis às alterações de pressão atmosférica.

Logo após, uma das mais referenciadas (como 41,6\% dos entrevistados) foi a Seriema (Cariama cristata), e que está representada na Figura 5. Sua distribuição se dá na América do Sul, nos países como o Brasil, Bolívia, Paraguai, Uruguai e Argentina. No casso do RS, são encontradas nas áreas mais arborizadas, no entanto também estão ocupando áreas de pastagens feitas pelo homem (SERIEMA, MANUAL DE MANEJO, 2013).

\section{Figura 5 - Seriemas cantando no turno da manhã na localidade de Aparecida.}

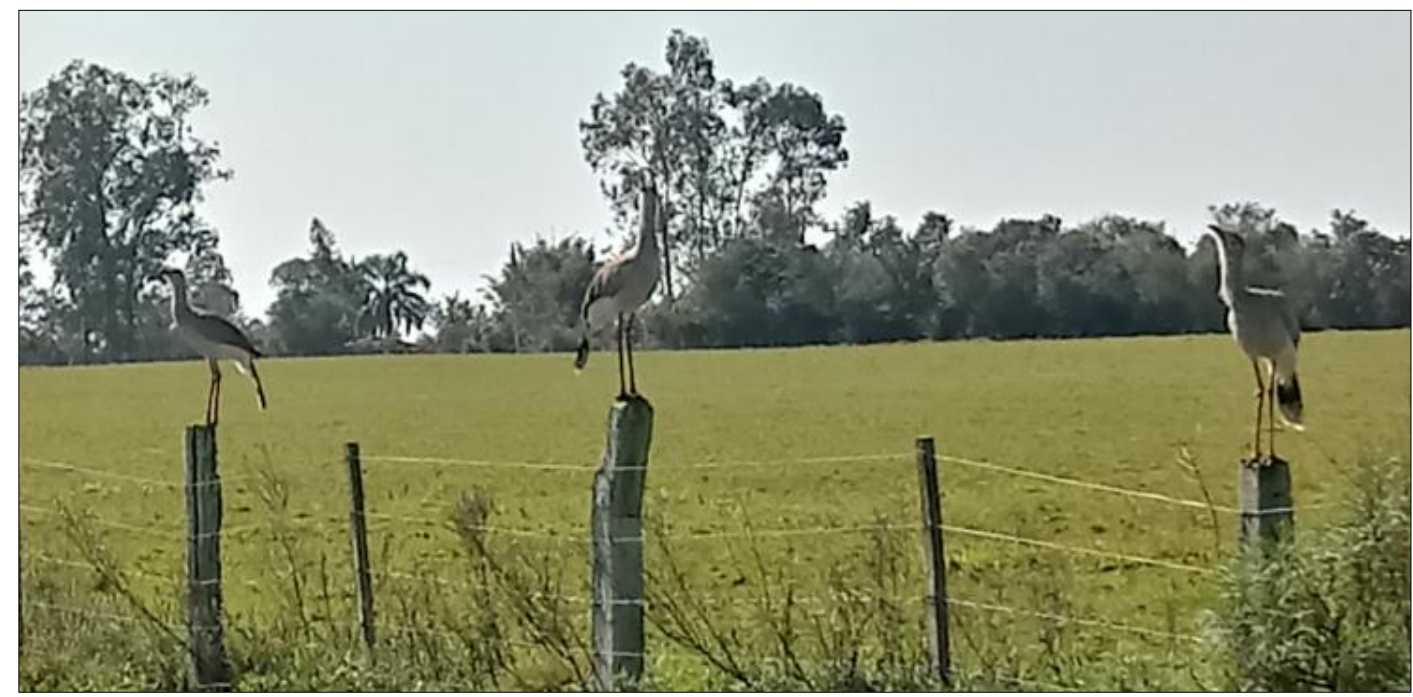

Fonte: Acervo particular dos autores (2019). 
A seriema também se alimenta de insetos, roedores e repteis (pequenas cobras e lagartos). Elas são aves de médio porte que, ao invés de voar, preferem correr, sendo que ainda seu canto geralmente é no turno da tarde. Por conseguinte, segundo a população das comunidades de Pedregulho e Aparecida, a "Seriema quando canta é sinal de chuva". Dois dos moradores especificaram, ainda, que "quando o canto é de manhã ocorre precipitações nos próximos dias".

Sartori (2005, p. 7) explica a atitude incomum da seriema colocando que a ave é "[...] sensível ao vento, e provavelmente também à pressão atmosférica [...]". As mudanças de direção e velocidade do mesmo, características das fases pré-frontais, provocam reações nesses seres vivos, que, através de seus cantos em horários fora do habitual, torna-se um importante indicativo de chuva para os humanos.

Nessa perspectiva, o comportamento do Gado (bovinos) apresentou o total de 33,4\% do número de citações feitas sobre o mesmo. Os moradores de Pedregulho e Aparecida ressaltaram que o gado é um importante indicador para se perceber as mudanças de tempo que estão ocorrendo, principalmente nas tempestades. Um ditado bem expressivo em relação à essa conduta, com $21 \%$ da população que citaram, diz que "Quando o gado se embola antes da chuva, vem temporal ou muita chuva."

Na busca por explicações científicas, apenas foi encontrado o estudo de Sartori (2003, 2005) que resgatou os fatos sobre a reação dos bovinos prestes as mudanças de tempo, propriamente ditas. Os demais trabalhos lidos eram, basicamente, sobre o clima e o aumento da produção leiteira, de manejo, que não resgatam o conhecimento empírico, a observação e a percepção climática sobre esse comportamento distintos.

Desse modo, Sartori $(2003,2005)$ salienta que o gado é sensível à pressão atmosférica, pois pressentem quando esse elemento climático diminui, reunindo-se, de imediato, em grupos ou refugiando-se em seus abrigos (estrebarias), como forma de se protegerem das chuvas intensas ou dos temporais que estão próximos. Em contra partida, se permanecerem quietos, pastando no campo, é um indicador de bom tempo.

Os últimos ditados sobre os animais mais rememorados pela população das localidades estudadas foi sobre o comportamento das galinhas e os galos em face das 
condições de tempo (28,8\% dos indivíduos rememoraram). Alguns os moradores expressaram, em seus ditos populares, que "As galinhas, antes da chuva, se esponjam na terra" (Figura 6).

Figura 6 - Galinhas se "esponjando" no solo na localidade de Aparecida.

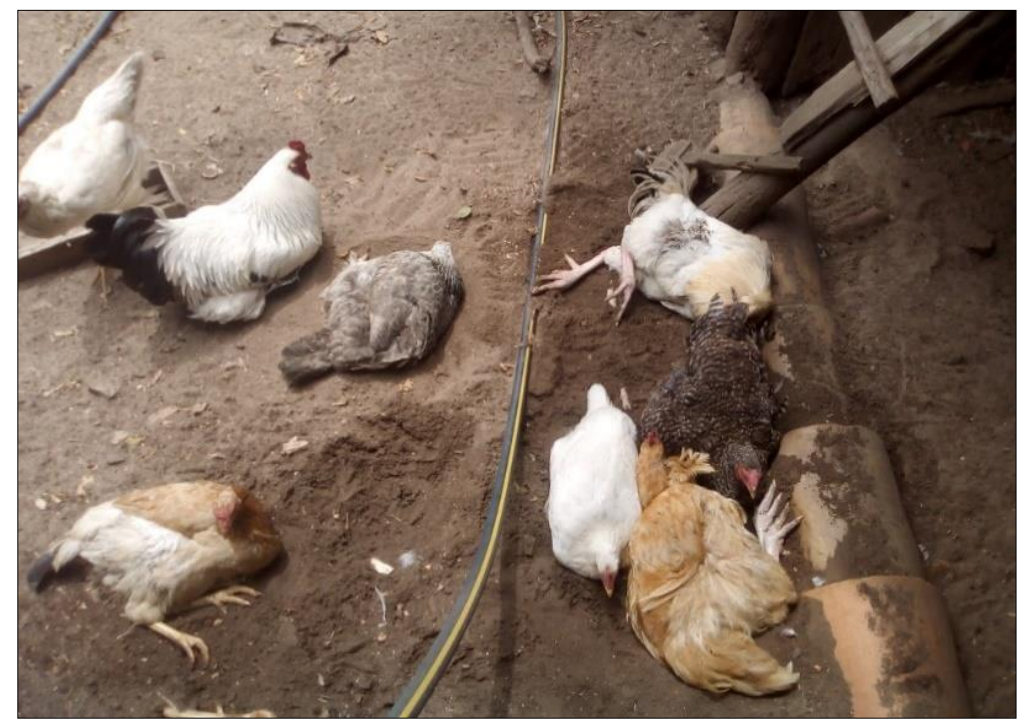

Fonte: Acervo particular dos autores (2019).

A temperatura é, nesse sentido, o elemento climático que mais influência/afeta os frangos, pela constante busca pelo conforto térmico, como enfatizam Santos et al (2012, p.1780). Colocam ainda que essas aves são animais "homeotermos", ou seja, seus sistemas fisiológicos trabalham o tempo todo para manter sua temperatura interna em cerca de 41 ${ }^{\circ} \mathrm{C}$.

Logo, o comportamento diferente das galinhas, de certa forma, pode ser esclarecido pela busca de conforto térmico com o ambiente externo, visto que em baixo das arvores o solo não está aquecido e faz com que essas aves "tomem seus banhos de areia" para se resfriarem, principalmente com as altas temperaturas que ocorrem antes das precipitações. Assim, essa conduta faz com que o ser humano, pelo seu tempo de permanência/experiência, perceba as condições meteorológicas futuras.

Por fim, entre os ditados sobre os animais, o mais citado pela população das duas localidades (com 25\% dos moradores que o referiram) foi do joão-de-barro (Furnarius rufus). No Brasil, é um dos pássaros mais populares e que habita tanto regiões urbanas, quanto rurais (MARREIS; SANDER, 2006). Portanto, os moradores de ambas as comunidades 
salientam, através de seus conhecimentos empíricos, que a ave sempre faz a abertura de sua casa na direção contrária ao ventos, principalmente das tempestades.

Desse modo, o joão-de-barro, como salienta Sartori (2005, p.9-10), possuí um conhecimento bem apurado de seu território, pois, em casais, circulam uma área de 100 a $200 \mathrm{~m}^{2}$ ao redor de seu ninho, conhecendo o espaço físico em detalhes. Portanto, o tempo de experiência em uma área tão pequena, faz com que essa ave perceba "[...] o clima em micro e mesoescla, hierarquicamente dependente da circulação atmosférica regional [...]". Através de seu conhecimento, constrói, como forma de proteção, seu ninho com a abertura oposta à direção habitual das chuvas e dos ventos mais característicos da região.

\subsection{Ditos populares sobre as observações das condições atmosféricas e céu}

O segundo grupo de ditados que se agrupou e, depois, se explicou foi sobre as condições de céu, as nuvens e os ventos, com o total de sessenta e um (61) ditos rememorados pelas duas localidades. Assim como os que eram referentes aos animais, muitos ditos se repetiram várias vezes, sendo foram, após a aglutinação, apresentados no Quadro 2.

Quadro 2 - Os ditados populares em face das condições de céu

\begin{tabular}{|c|c|c|}
\hline $\begin{array}{c}\text { Ditados populares das condições de céu, vento, } \\
\text { nuvens, pôr do sol }\end{array}$ & $\begin{array}{c}\mathrm{N}^{\circ} \text { de vezes } \\
\text { que os } \\
\text { ditados } \\
\text { foram } \\
\text { citados }\end{array}$ & $\begin{array}{c}\% \text { em relação } \\
\text { ao n de } \\
\text { moradores } \\
\left(\mathrm{N}^{\circ}=24\right)\end{array}$ \\
\hline $\begin{array}{c}\text { "Quando tem nuvem rabo de galo no céu é sinal de } \\
\text { chuva" }\end{array}$ & 12 & 50 \\
\hline "Pôr do sol com barra escura, chove no outro dia" & 8 & 33,3 \\
\hline $\begin{array}{c}\text { "Pôr do sol bem vermelho depois de muita chuva } \\
\text { significa estiagem" }\end{array}$ & 3 & 12,5 \\
\hline $\begin{array}{c}\text { "Barra escura no pôr do sol é sinal de chuva pra } \\
\text { madrugada ou no outro dia." }\end{array}$ & 1 & 4,1 \\
\hline "Três dias de vento norte e chove" & 10 & 41,6 \\
\hline
\end{tabular}




\begin{tabular}{|c|c|c|}
\hline "Vento minuano dá tempo bom" & 7 & 29,1 \\
\hline "Vento minuano da aquela friagem." & 1 & 4,1 \\
\hline "Cerração que baixa, sol que racha" & 6 & 25 \\
\hline "Noite estrelada não chove" & 2 & 8,3 \\
\hline $\begin{array}{c}\text { "Quando dá pra escutar o trem na cidade tá de } \\
\text { chuva" }\end{array}$ & 4 & 16,6 \\
\hline "Quando tem círculo no sol é sinal de chuva" & 3 & 12,5 \\
\hline "Sol e chuva, casamento de viúva." & 2 & 8,3 \\
\hline "Fumaça subindo reto é chuva que vem" & 1 & 4,1 \\
\hline "Fumaça do fogão subindo reto é sinal de chuva" & 1 & 4,1 \\
\hline
\end{tabular}

Fonte: Arquivo pessoal dos autores (2019).

Após a análise do Quadro 2, verificou-se que os ditados mais citados sobre as condições de céu na área de estudo foram do deslocamento e formação das nuvens, as mais conhecidas pela população rural como "rabos de galo" (com $50 \%$ dos entrevistados que citaram). Os moradores colocaram que quando essas nuvens aparecem é sinal de mau tempo, que irá chover em breve. Essas nuvens são as cirros, que, segundo Sartori (2003, 2005), são comuns nas fases pré-frontais, são as primeiras e também mais altas, sendo importantes indicativos da aproximação das frentes (FPA) no RS.

No que diz respeito à nebulosidade, um dos ditados que apareceram foi sobre as "barras escuras no pôr do sol", como presságio de chuva para os próximos dias (com 38,4\% dos entrevistados que rememoraram). Sartori (2005, p. 11) coloca que o horizonte está encoberto por nuvens volumosas no quadrante oeste, "[...] associadas à aproximação de frentes frias (FPA) na região, que sempre penetram por esse quadrante em seus deslocamentos de sudoeste para nordeste no hemisfério sul", o que explica a percepção dos moradores.

Muitos dos sujeitos também rememoraram um ditado sobre o vento norte $(41,6 \%$ dos moradores o referenciaram). Conforme os moradores, são "Três dias de vento norte e chove". Isso pode ser explicado porque esse vento é pré-frontal, ou seja, atua, mais ou menos três dias e depois é interrompido pela frente fria que avança pelo RS (SARTORI, 2016).

Outro vento que se destacou através dos ditos populares foi o minuano $(33,2 \%$ dos indivíduos o citaram). Conforme a população das localidades de Pedregulho e Aparecida, quando esse vento está atuando é sinal de tempo bom e de temperatura mais baixa. 
O vento minuano, de acordo com Mariante (1985), é um dos mais conhecidos pela população gaúcha. Caracteriza-se por ser seco e frio, que teve sua origem na Cordilheira dos Andes e que geralmente atua por três dias seguidos, depois das chuvas, trazendo um período de mais estabilidade/estiagem.

Em seguida, os entrevistados expressaram que "Cerração que baixa, sol que racha" (com $25 \%$ de pessoas que o rememoraram). Sartori (2005, p.15) explica que isso se dá porque os nevoeiros, principalmente do período que vai de março até setembro, são comuns na região central do Estado do RS e ocorrem pela presença da MPA. A autora ressalta que "[...] as condições atmosféricas (grande insolação, umidade e céu limpo) favorecem a perda de radiação terrestre noturna, o resfriamento do ar e a condensação da umidade. Como o céu está limpo, as primeiras horas de insolação matinal dissipam o nevoeiro e o sol brilha forte."

Os moradores rememoraram, também, que "Quando tem um círculo ao redor do sol é sinal de chuva.". Schmidt (1994) ressalta que o fenômeno recebe o nome de "Halo", e que se pode observar quando tem nuvens do tipo cirros estratos, de grandes alturas e que são causadas pela presença de cristais de gelo. Ainda, segundo o autor, esses círculos podem ser brancos ou coloridos. Sartori (2005, p. 11-12) enfatiza que esses halos "[...] antecedem a chegada de frentes (FPA), estendendo-se no céu como tênue e contínuo véu a encobrir o Sol ou a Lua."

Outro dito que a população da área de estudo rememorou foi de que "Noite estrelada não chove" (8,3\% das pessoas o referenciaram). A explicação sobre o dito recai nos períodos que não possuem nenhuma faixa de nebulosidade, isto é, sem o domínio de sistemas frontais, o que possibilita às pessoas visualizarem as estrelas, a lua e, consequentemente, as condições de bom tempo para o outro dia (SARTORI, 2005).

No prosseguimento, os moradores colocaram que "Quando dá pra escutar o trem na cidade tá de chuva." O efeito da propagação desse som/barulho, como coloca Sartori (2003, 2005), está relacionado com a direção do vento nas fases pré-frontais e que depende do local onde está o observador para escutá-lo.

Além do mais, conforme os entrevistados, "Pôr do sol bem vermelho depois de muita chuva significa estiagem." Demostra que não há mais a aproximação de frentes frias, sendo 
que, como explica Sartori $(2003,2005)$, o vermelho mais intenso nesse período do dia e especialmente após a chuva se dá por causa da difusão do comprimento de ondas, das partículas de poeiras (aerossóis) que estão em suspensão e da umidades nas camadas mais altas que resultam em tal aspecto.

Para finalizar, apenas um dos moradores citou que "Quando a fumaça do fogão sobe reto é sinal de chuva". Por conseguinte, embora apenas uma pessoa citou esse ditado, existe explicação científica para o mesmo, pois Sartori (2003) o esclarece, colocando que devido aos maiores aquecimentos que se dão ao longo das fases pré-frontais e com uma menor velocidade dos ventos (calma) a fumaça tende a subir.

\subsection{Ditados populares sobre o clima e as fases da lua}

O último grupo de ditados populares sobre o clima, rememorados pelos sujeitos das localidades de Pedregulho e Aparecida, foi acerca da lua (Quadro 3). No geral, os moradores não apresentaram muitos ditos sobre esse astro, sendo que o número total ficou em dezenove (19). Um fato bastante interessante é que boa parte dos entrevistados não possuíram ditos sobre o clima e a lua, mas ressaltaram que geralmente se baseiam nas fases lunares para desenvolverem os seus cultivos na propriedade.

\section{Quadro 3 - Os ditados populares referentes às fases da lua:}

\begin{tabular}{|c|c|c|}
\hline Ditados populares sobre a lua e o clima & $\begin{array}{c}\mathrm{N}^{\circ} \text { de } \\
\text { ditados } \\
\text { citados }\end{array}$ & $\begin{array}{c}\% \text { desses ditos } \\
\text { em relação ao n } \\
\text { de residentes (n } \\
=24)\end{array}$ \\
\hline $\begin{array}{c}\text { "Lua nova faz muito barulho, muita troada, } \\
\text { relâmpago" }\end{array}$ & 3 & 12,5 \\
\hline "Lua nova dá mais tormenta" & 3 & 12,5 \\
\hline "Círculo na lua, ou tá de chuva ou de cerração" & 5 & 21 \\
\hline "Quando a lua não tá inteira, tá com a boca virada \\
para baixo, tá pra chover" & 3 & 12,5 \\
\hline "Geralmente chove na troca de fase das luas" & 2 & 8,3 \\
\hline "Quando tá de chuva, chove na entrada ou na saída \\
da lua"
\end{tabular}




\begin{tabular}{|c|c|c|}
\hline $\begin{array}{c}\text { "A cada mudança de lua a cada } 7 \text { em } 7 \text { dia o tempo } \\
\text { também muda" }\end{array}$ & 1 & 4,1 \\
\hline
\end{tabular}

Fonte: Arquivo pessoal dos autores (2019).

Na análise do Quadro 3, observa-se que os ditados mais citados pela população rural foram sobre a lua nova (25\% dos envolvidos os citaram). Segundos os moradores, quando o astro se encontra nessa fase as tormentas são mais severas, com mais raios, trovoadas, relâmpagos, enfim, são temporais bem mais conturbados. Além do mais, alguns dos entrevistados (16,6\% da população) citaram que durante as transições das fases lunares é mais fácil de ocorrerem as precipitações. Desse modo, na busca por explicações científicas, foram apenas os trabalhos de Cunha (1997) e de Sartori (2003, 2005) que fazem considerações a respeito da lua e o clima.

Cunha (1997, p. 123) coloca que não é possível prever o tempo com bases nas fases da lua. Segundo ele, por muito tempo foi disseminado, em forma de almanaques, vários provérbios sobre a meteorologia e esse astro pelo Brasil. Salienta que é impossível prever uma mudança de tempo a partir da observação lunar e que há uma razão lógica para isso. Conforme ele, a lua muda de fase para todos os lugares do mundo no mesmo dia. Logo, se a observação das mudanças de fases da mesma indicassem a previsão de chuvas, por exemplo, esse fenômeno deveria ocorrer em uma esfera mundial, reforçando de que não é possível prever o tempo com base no astro.

Atribuir explicações para os ditados que envolvem a lua são muito difíceis de serem realizadas, como ressalta Sartori $(2003,2005)$. Em seus trabalhos sobre a percepção climática na região central do RS, a autora encontrou vários provérbios sobre a lua nova, principalmente, que influenciavam nos processos atmosféricos, no entanto, por necessidade de síntese, não apresentou explicações para esses provérbios.

Dessa forma, é interessante que os ditados encontrados por Sartori $(2003,2005)$ são muito parecidos com os que foram encontrados no presente trabalho, reafirmando suas pesquisas. De certa maneira, envolvem a mesma área de estudo, mas vale ressaltar que as escalas são diferentes, pois ela fez seus estudos de modo mais amplo, isto é, com a escala regional e local, já neste trabalho foram feitas as investigações com base nesta última. 


\section{CONCLUSÕES}

Nas duas localidades rurais de Pedregulho e Aparecida, no município de Restinga Sêca, RS, os moradores rememoraram um número bem expressivo de ditados populares sobre o clima. No total, foram cento e trinta (130) ditos populares a respeito do comportamento da fauna frente aos processos atmosféricos; sessenta e um (61) em face das condições atmosféricas de céu, que envolveram o pôr do sol, halo, nuvens e, para finalizar, dezenove (19) expressões sobre a lua e as condições atmosféricas.

Todos os ditos mais citados pela população rural das comunidades de Aparecida e Pedregulho que dizem respeito ao comportamento anormal dos animais foram esclarecidos. Sobre os ditados das condições de céu, nuvens, ventos, pôr do sol e halos também foram explicados acerca da revisão bibliográfica. O grupo de provérbios sobre a lua e o clima, embora não fossem encontrados estudos que os desvendassem, foram expostos os autores que fazem considerações acerca desses fenômenos.

A percepção climática da população da área de estudo, acerca da investigação e análise dos ditados/expressões populares sobre o clima, evidenciou que as sessões pelo sentido da visão e da audição influenciaram grandemente na sabedoria popular/conhecimento empírico dessas pessoas. No grupo dos animais, por exemplo, se destacaram o canto, o ronco, o mugido e o coaxar dos mais diversos animais, e na observações em face da visão ocorreu através do relato das nuvens, dos halos e do pôr do sol.

\section{REFERÊNCIAS}

AYOADE, J. O. Introdução à climatologia para os trópicos. 5. ed. Rio de Janeiro: Bertrand Brasil, 1998.

BASTOS, S; FUENTES, M. C. O uso da etnoclimatologia para a previsibilidade de chuvas no município de Retirolândia - BA. Revista do Ceres, v. 1, p. 176 - 183, 2015.

BICHO DA CHUVA. Ênio Medeiros. Disponível em: <https://www.youtube.com/watch?v=z2erQtU6gdc> Acesso em: 13 de jan. de 2019.

CLAUSSE, R. Meteorologia e folclore: que vale para o cientista os ditados e crendices sobre chuva e bom tempo? In: O CORREIO. Os segredos da chuva e do bom tempo. Outubro/ novembro, 1973.

CUNHA, G. R. Meteorologia: Fatos \& mitos. 1 ed. Passo Fundo: Embrapa Trigo, 1997. 
28 | Os ditados populares sobre o clima rememorados pela população rural das localidades de pedregulho e aparecida, no município de restinga sêca, RS

GUZZO, G. B. Ecologia e comportamento de Alouatta guariba clamitans Cabrera, 1940, em um fragmento de mata de araucária na Serra Gaúcha. 2009, 60 p. Dissertação (Mestrado em Zoologia) Pontifícia Universidade Católica do Rio Grande do Sul, Porto Alegre, RS, 2009.

INSTITUTO BRASILEIRO DE GEOGRAFIA E ESTATÍSTICA. Cidades e Estados. 2010. Disponível em < https://www.ibge.gov.br/cidades-e-estados/rs/restinga-seca.html>. Acesso em: 05 de set. de 2019.

MARREIS, I. T; SANDER, M. Preferência ocupacional de ninhos de joão-de-barro (Furnarius rufus, Gmelin) entre área urbanizada e natural. Biodiversidade Pampeana, 2006. Disponível em <http://revistaseletronicas.pucrs.br/ojs/index.php/biodiversidadepampeana/article/viewFile/2576/2 000> Acesso em: 03 de nov. de 2019.

MARIANTE, H. M. Santa Bárbara, São Jerônimo! (Meteorologia e astronomia populares no RS). Porto Alegre, Martins Livreiro, 1985.

MONTENEGRO, A. F. Ceará e o Profeta de chuva. Fortaleza: Edições UFC, 2008.

OLIVEIRA, F. L; NUNES, L. H. A percepção climática no município de Campinas, SP: confronto entre morador urbano e rural. Geosul, Florianópolis, 2007.

PADATA, Z. Cores do céu - Meteorologia popular nos provérbios portugueses. Romanica Olomucensia, 2015. Disponível em: <file:///C:/Users/User/Downloads/Dialnet-CoresDoCeu5398094\%20(1).pdf> . Acesso em: 08 de set. de 2019.

ROUSO, D. O clima de Santa Cruz do Sul - RS e a percepção climática da população urbana. 2007. 172 p. Dissertação (Mestrado em Geografia) - Universidade Federal de Santa Maria, Santa Maria, 2017.

SANTOS, M. J. B. et al. Fatores que interferem no estresse térmico em frangos de corte. Revista Eletrônica Nutritime, artigo número 162, v.9, 2012. Disponível em: < https://www.nutritime.com.br/arquivos_internos/artigos/162_ebook_Maio_2012_.pdf >. Acesso em: 28 de out. de 2019.

SARTORI, M. G. B. A dinâmica do clima do Rio Grande do Sul: indução empírica e conhecimento científico. Revista Terra Livre, São Paulo, v. 1, n. 20, p. 27-49, jan./jul. 2003.

SARTORI, M. G. B. A percepção do tempo e a cognição ambiental do homem rural do Rio Grande do Sul. In: SIMPÓSIO NACIONAL SOBRE GEOGRAFIA, PERCEPÇÃO E COGNIÇÃO DO MEIO AMBIENTE, 1. 2005, Londrina. Anais... Londrina: UEL, 2005. 1 CD-ROM.

SARTORI, M. G. B. Clima e percepção geográfica: fundamentos teóricos à percepção climática e à bioclimatologia humana. Santa Maria: Pallotti, 2014.

SARTORI, M. G. B. O vento norte. Santa Maria, Pallotti, 2016.

SERIEMA, MANUAL DE MANEJO. Seriema (Cariama cristata) manual de manejo. Association Ofzoos \& Aquariums, 2013. Disponível em: <http://docplayer.com.br/26568243-Seriema-cariama-cristatamanual-de-manejo.html >. Acesso em: 05 de set. de 2019.

SCHMIDT, E. M. S; GABRIEL, E. M. N. Saracura: Aramides saracura (Spix, 1825). Disponível: < http://books.scielo.org/id/ckwyb/pdf/schmidt-9788579837579-19.pdf >. Acesso em: 03 de ago. de 2019. 
SCHMIDT, R. Você e a meteorologia: acertos, erros e dicas. 1 ed. Porto Alegre: Sagra Luzzatto, 1994.

TUAN, Y. Topofilia: um estudo de percepção, atitudes e valores do meio ambiente. São Paulo: DIFEL, 1980.

TUAN, Y. Espaço e lugar: a perspectiva da experiência. São Paulo: DIFEL, 1983.

VOOS, W. A. A relação meteorologia popular/ animais. In: MARIANTE, H. M. Santa Bárbara, São Jerônimo! (Meteorologia e astronomia populares no RS). Porto Alegre, Martins Livreiro, 1985.

WHYTE, A. T. Guidelines for fields studies in environmental perception. MAB Technical Notes 5. Paris, UNESCO, 1977. 19 p.

WOLLMANN, C. A; SARTORI, M. G. B. A percepção ambiental e climática da população de são Sebastião do caí como forma de previsão de enchentes na bacia hidrográfica do Rio Caí - Rio Grande do Sul. Revista Brasileira de climatologia, v. 6. Jun. 2010.

WOLLMANN, C. A; GLAVANI, E. A percepção e cognição climática dos agricultores e pesquisadores como subsídio ao cultivo de roseiras no Rio Grande do Sul. Ciência e Natureza, Santa Maria, v. 35, n. 1, 2013. 